\title{
Sarcasm in Indonesian Political Culture
}

\author{
Farida Nugrahani ${ }^{1}$, Mukti Widayati ${ }^{2}$, Wiwik Darmini ${ }^{3}$, Titik Sudiyatmi ${ }^{4}$, Ali Imron AM ${ }^{5}$ \\ 1,2,3,4 University of Veteran Bangun Nusantara Sukoharjo, Indonesia \\ ${ }^{5}$ University of Muhammadiyah Surakarta, Indonesia
}

farida.nugrahani01@gmail.com

\begin{abstract}
This study reviews the use of language in political propaganda on beritasatu.com. His research focus on the sarcastic culture of political communication. The purpose of his research is to describe the tendency of the current political culture of Indonesian society, in choosing sarcastic diction for political propaganda. The study was conducted with a qualitative paradigm. The results show that Indonesians today are accustomed to using the style of sarcasm in political propaganda with the aim of insinuating or attacking political opponents. Sarcasm is a deviation of the pragmatic form of language use, namely impoliteness which is done intentionally for a particular purpose. The use of sarcasm in political propaganda leads to a culture of impoliteness which is a violation of the ethics of communication.
\end{abstract}

Keywords: Sarcasm; Political Culture; Impoliteness; Indonesia.

\section{INTRODUCTION}

Language as part of culture is one of the most effective means of communication between humans and is widely used by humans. Today, electronic news is the most effective means of public communication, because it is not limited by space and time[1]-[3]. Therefore, public opinion is easily formed through this media. Among other things to promote the program, imaging certain personal or figures, or open political propaganda in the public space.

The use of language can be adjusted to their needs. Therefore, the phenomenon of violations of language use must be understood by considering the context[2]. In this study, the context was limited to political propaganda in Indonesia, which was delivered through beritasatu.com electronic news. In news of political propaganda on beritasatu.com, there are comments, criticisms, input, and jokes that mean deviating pragmatically. These deviations appear in the use of sarcasm language styles openly, the effects of which are: 1) the perception of analogies arises that in general the Indonesian people like to use sarcasm, 2) the public is educated to use abusive language, 3 ) the development of permissive attitudes towards the use of language rude and not polite in the community[4].

Regarding to the possibility of this impact, it is important to pay attention to this problem, in order not to lead to the emergence of a new communication culture that deviates from the 
nation cultural character of Indonesia as an Eastern nation, which is well-known and friendly. Therefore, this research is important to be concerned.

Language style is a style of using language[5]. It is a way of expressing ideas, thoughts, and feelings according to creativity, personality, and soul to get certain effects from what they convey[6]. In general, this style of language is closely related to the sociocultural background of its users. Through the style of language a person can be known for his personality, because this language style is closely related to the sociocultural background of its users. There are four groups of classifications, namely the style of comparison, contradiction, linkage, and repetition. In accordance with this discussion, the style of language that is associated with rude speech and impoliteness is the style of sarcasm[3], [7].

Sarcasm is meant by scathing words to hurt others; ridicule or humiliation. Sarcasm contains satirical words intended to offend. Speeches containing sarcasm are generally used when giving criticism for an event or condition that is deemed inappropriate. Sarcasm is a more crude reference to irony and cynicism. Sarcasm contains bitterness and reproach that hurts the heart and is less pleasant to hear than the other person says[8]. Besides that it is also a mockery or insult to someone. Therefore, the use of sarcasm in the speech violates the ethics of communication, because it is not able to foster cooperation with its opponents[9]. Even though in fact, someone needs to prioritize ethics in speaking words, by paying attention to the norms that become a moral grip for the community in their group, so that communication runs well.

\section{METHODS}

This descriptive qualitative study, the purpose of which is to describe data in as much detail as possible from natural settings. The study of embedded case studies focuses on the use of sarcasm language styles for political propaganda. The purpose of his research is to reveal the current tendency of Indonesian society to use harsh words that has sarcastic meaning in political propaganda on beritasatu.com. The source of the data is a document in the form of writing about political propaganda which occurred pragmatic deviations of meaning on beritasatu.com. The sample was selected by purposive sampling. Data is collected through documentation techniques, listening, and taking notes [10]. The validity of the data is attempted through source triangulation and then analyzed by content analysis techniques through interactive models[10].

\section{RESULT AND DISCUSSION}

\subsection{Sarcasm language style through code mixing}

Research data shows that the language used in electronic news has quite varieties, namely Indonesian language has a variety of languages, mixed languages, regional languages and foreign languages. From its meaning, it is known that many utterances experience pragmatic deviations of meaning. The deviation can be seen from the existence of the elements of sarcasm in speech, such as the use of rude words, curse, satire, ridicule, and disrespectful or demeaning and insulting terms[11].

Data in the field shows that many speakers in electronic news use mixed Indonesian, which is Indonesian language mixed with regional or foreign languages. The symptoms of this language are in the interference group, code switching and code mixing. Interference is one form of disruption in the use of language as a result of bilingualism, or multilingualism[12]. 
Code switching is a symptom of the transition of language use due to changing situations, and code mixing is a symptom of the use of two languages by consistently incorporating elements of one language into another language[1], [13].

The reason for language users to do code switching and code mixing in general is as follows. 1) the language used is better to describe his thoughts and feelings appropriately. 2) there is no appropriate term for expressing thoughts and feelings. In the case of sarcasm, the choice of diction from other languages seems to always be done to show the background of the speakers' ethnic groups to electronic news readers. The data is presented in the following table.

Table 1. Sarcasm language style through Code Mixing with Javanese language

\begin{tabular}{ccc}
\hline Data & Meanings & Purpose \\
\hline Bintang Kecil: "wong wis tuek yo & Old people, have passed & Presenting ridicule, \\
kakehan gaya sih, penak2 nang & the age to be officials, but & sarcasm with abusive \\
umah momong putu kok ndadak & still wants to be elected as & words to others whom \\
pecicilan nyawapres...."(1) & president & the speaker dislike. \\
Anonim: Haa..ha..yang biasa & Criminals even accuse & $\begin{array}{c}\text { Defending the candidate } \\
\text { by demeaning his }\end{array}$ \\
kasus begono mah, semua tau. (2) & others of committing their & crimes. \\
Neo: "Sri Paus? Klau Prabowo & The presidential candidate & Expressing displeasure, \\
menang negeri ini bakal jadi antek2 & in question, if elected will & distrust of candidates \\
setan arab berjanggut, & be a subordinate to the evil & because they are close to \\
hehehehehehe."(3) & Arabs. & other nations. \\
\hline
\end{tabular}

Besides being found using Indonesian language mixed with some codes in Javanese language, we also found data on the use of mixed Indonesian language codes with foreign languages, English and Arabic. In general, this is done intentionally in order to appear educated, or modern. The use of terms from Arabic is generally done with the aim of being religious. English and Arabic dictionaries used, are appear in the following data.

Table 2. Code Mixing with Foreign Language (Arabic, English)

\begin{tabular}{|c|c|c|}
\hline Data & Meanings & Purpose \\
\hline $\begin{array}{c}\text { Anonim: Track record Prabowo gak } \\
\text { bagus, punya keluarga bercerai. } \\
\text { Jadi tentara/TNI dipecat. Apakah } \\
\text { orang semacam ini akan dipilih } \\
\text { menjadi pemimpin? (4) }\end{array}$ & $\begin{array}{c}\text { The candidate's } \\
\text { background is not good. }\end{array}$ & $\begin{array}{c}\text { Dropping someone's } \\
\text { good name by showing } \\
\text { various negative facts as } \\
\text { a drawback. }\end{array}$ \\
\hline $\begin{array}{c}\text { "Jika Prabowo terpilih menjadi } \\
\text { presiden negeri ini masih memiliki } \\
\text { harapan. Tapi jika yang satunya } \\
\text { terpilih, maka celakalah rakyat } \\
\text { negeri ini, naudzubillah mindhalik". } \\
\text { (5) }\end{array}$ & $\begin{array}{l}\text { Candidates are good } \\
\text { people, but the opponent is } \\
\text { a bad person, so the } \\
\text { speaker wants to be kept } \\
\text { away from his opponent. }\end{array}$ & $\begin{array}{l}\text { Reveal disgust and hatred } \\
\text { to someone }\end{array}$ \\
\hline
\end{tabular}

\subsection{Sarcasm in utterances which means connotation}


Another phenomenon found through speech in electronic news is the use of phrases or terms that has figurative meaning[14], among others: otak kosong (empty brain) (6), buta mata hatinya (blind eyes) (7), penggarong (mafia) (8), omong besar (big mouth) (9), and gila jabatan (crazy position) (10). They are all used in a meaningful negative speech for the purpose of attacking his opponent. Here are the data quotes.

Table 3. Sarcasm in utterance which means connotation

\begin{tabular}{|c|c|c|}
\hline Data & Meanings & Purpose \\
\hline $\begin{array}{c}\text { Anonim: ... hanya yang otaknya } \\
\text { kosong yang dukung jokowi (6) }\end{array}$ & $\begin{array}{l}\text { Only people who can't } \\
\text { think who wants to choose } \\
\text { Jokowi. }\end{array}$ & $\begin{array}{l}\text { Insulting with harsh } \\
\text { words. }\end{array}$ \\
\hline $\begin{array}{l}\text { Sugeng Ndalu: Laiyah, sampe } \\
\text { segitunya bela penyakit HAM. } \\
\text { Sudah buta mata hatinya diliputi } \\
\text { kebencian sama jokowi.."(7) }\end{array}$ & $\begin{array}{l}\text { Embarrassing because it } \\
\text { still defends people who } \\
\text { are seen as violating } \\
\text { human rights. }\end{array}$ & $\begin{array}{l}\text { Use harsh words to } \\
\text { express hatred. }\end{array}$ \\
\hline $\begin{array}{c}\text { "Prabowo mengiklankan diri } \\
\text { menjadi calon presiden, koalisinya } \\
\text { adalah kumpulan mafia } \\
\text { penggarong". (8) }\end{array}$ & $\begin{array}{l}\text { Prabowo's supporters are } \\
\text { bad people who belong to } \\
\text { the group of thieves. }\end{array}$ & $\begin{array}{l}\text { Use harsh words to } \\
\text { express hatred, and aim } \\
\text { to humiliate and ridicule. }\end{array}$ \\
\hline $\begin{array}{c}\text { Bejo Al-bantani: . "ini dia bukti } \\
\text { bahwa Prabowo cuma modal } \\
\text { omong besar." (9) }\end{array}$ & $\begin{array}{l}\text { Prabowo only bragged. } \\
\text { Mistake cannot be trusted. }\end{array}$ & $\begin{array}{l}\text { Conveying dislike and } \\
\text { humiliation with harsh } \\
\text { words }\end{array}$ \\
\hline $\begin{array}{c}\text { Akhmad: “@Neo, Jokowi kan gila } \\
\text { jabatan.paling } 2 \text { tahun kalo } \\
\text { menang jadi presiden mulai lirik2 } \\
\text { jabatan baru lagi”. (10) }\end{array}$ & $\begin{array}{l}\text { Jokowi likes to pursue } \\
\text { positions and is never } \\
\text { satisfied with positions } \\
\text { that he has been occupied. }\end{array}$ & $\begin{array}{l}\text { Conveying dislike and } \\
\text { insulting with rude and } \\
\text { impolite rude words. }\end{array}$ \\
\hline
\end{tabular}

From the citation of the data presented above, it can be shown that the use of sarcasm as seen from the diction is roughly crude, to express dislike of the opponents he said. In the context of political propaganda, opponents say that it is people who have or participate in a political party or alliance that is different or opposes him. The sarcasm in question appears in the use of the following words. naudzubillah mindhalik (5), which means that may Allah protects. These words are spiritual terms, which are generally used by people to respond to bad news. If this word is delivered to refer to the behavior of the opponent, then this is very rude and painful for the intended person. The meaning of sentence (5) is that the news that has just been heard is bad and terrible news. Of course this sentence is very rude and awful. Selection of diction is tuek (1) to replace the word old; the word pecicilan to say 'lots of actions, or lots of desires'; 'anthek' (3) to declare 'accomplices'; the word dipecat (5) to declare 'dismissed'; it's the choice of words that violate politeness, are rude, impolite and inappropriate. Sarcasm language that occurred in electronic news can be read by everyone in public, this is very unwise and shows an unfavorable character. Therefore, it violates moral norms in the ethics of cultural and well-mannered character of the society.

Meanwhile, in the election of diction 'setan arab berjanggut' (3), which is meant to say that 'the Arabian is as evil as the devil' also shows that the sentence is very sarcastic. This violates the rules of ethnicity, race, and religion, because it relates to other nations (Arabian) that should be respected and their kinship is established. Besides that the bearded word is also 
synonymous with referring to Muslims. Generalizing the meaning that Arabians are evil like setan is very weak in its documentation and even primordial. Therefore this sentence is a speech that violates the rules of ethnicity, race, and religion that are strictly prohibited in a legal country such as Indonesia.

The selection of diction which means degrading someone's dignity is also seen in the phrase Prabowo cuma modal omong besar (9). Prabowo is a former general army who is seen only with a false speech, of course, very insulting and unreasonable. Because in reality Prabowo is a highly respected national leader. The sentence is certainly not appropriate, and not in accordance with reality. The sentence is certainly written only for the purpose of demeaning, or expressing hatred for the subject intended.

This sarcasm on beritasatu.com reflects that Indonesian society is the speaker of a language that is poor in culture, does not have good character and does not uphold ethics of politeness in language. This kind of thing if left unchecked will have an increasingly widespread influence, and make it a new culture so that it diminishes the character of the Indonesian people who are known as Eastern people who are friendly, polite and have [15].

Indonesian is a national language as well as the language of the country, it is appropriate for the Indonesian people to respect the position of the language as strengthened in the 1945 Constitution Chapter XV, Article 36. In this regard, all Indonesian people must be positive towards the Indonesian language shown by using it well and politely. The government has regulated this through Law Number 24 Year of 2009, in Article 3 of the National Education System Law, which defines that national education functions to develop capabilities and shape dignified character and national civilization in order to educate the nation's life, aimed to developed potential students in order to be a man that is faithful and fear of God Almighty, noble, healthy, knowledgeable, capable, creative, independent, and being a democratic and responsible citizen.

Responding to the phenomenon of the use of that sarcasm, it is important to carry out counseling to all Indonesian people, on all fronts. In the position of the Indonesian nation that is multiculturalism, with various ethnics, races and religions, the role of Indonesian language as a unifier tool is predominant and very important [16].

\section{CONCLUSION}

From the discussion above, it can be concluded that there are pragmatic deviations in the use of language on Indonesian electronic news. This can be seen from the many language styles of sarcasm. In the context of this political propaganda, the style of sarcasm is deliberately used by speakers to express hatred, dislike, or to insult, humiliate, demean, or make verbal attacks to people who are political opponents. The attacks sarcastically delivered are explicit and some are implicit.

The sarcastic expression on electronic news shows the impoliteness of Indonesian people in language. This reflects that it has actually been a fading character of the Indonesian people as the Eastern nation that commonly known as friendly, polite and highly cultured. If this is left over, it will ruin the character which is the identity of the Indonesian nation as a dignified nation.

\section{ACKNOWLEDGMENTS}


Thank you to the DRPM Ministry of Research. Technology and Higher Education of Republic of Indonesia and LPPM University of Veteran Bangun Nusantara which have funded this research.

\section{REFERENCE}

[1] R. W. Gibbs, "On the psycholinguistics of sarcasm.," J. Exp. Psychol. Gen., vol. 115, no. 1, pp. 3-15, 1986.

[2] M. Berezin, "Politics and Culture: A Less Fissured Terrain," Annu. Rev. Sociol., vol. 23, no. 1, pp. 361-383, Aug. 1997.

[3] D. Halder and K. Jaishankar, "Cyber Gender Harassment and Secondary Victimization: A Comparative Analysis of the United States, the UK, and India," Vict. Offender., vol. 6, no. 4, pp. 386-398, Oct. 2011.

[4] E. Riloff, A. Qadir, P. Surve, L. De Silva, N. Gilbert, and R. Huang, "Sarcasm as Contrast between a Positive Sentiment and Negative Situation," in EMNLP 2013 - 2013 Conference on Empirical Methods in Natural Language Processing, Proceedings of the Conference, 2013.

[5] M. H. Abrams and G. Harpham, A glossary of literary terms. Boston: Cengage Learning, 2011.

[6] M. M. Marggraff, "Verb stems as stylistica in D.B.Z. Ntuli's Ucingo," South African J. African Lang., vol. 17, no. 4, pp. 135-139, Jan. 1997.

[7] A. Rajadesingan, R. Zafarani, and H. Liu, "Sarcasm Detection on Twitter," in Proceedings of the Eighth ACM International Conference on Web Search and Data Mining - WSDM '15, 2015, pp. 97-106.

[8] J.-M. Rueff, M. Poienar, A. Guesdon, C. Martin, A. Maignan, and P.-A. Jaffrès, "Hydrothermal synthesis for new multifunctional materials: A few examples of phosphates and phosphonate-based hybrid materials," J. Solid State Chem., vol. 236, pp. 236-245, Apr. 2016.

[9] H. S. Cheang and M. D. Pell, "The sound of sarcasm," Speech Commun., vol. 50, no. 5, pp. 366-381, May 2008.

[10] M. B. Miles and J. Huberman A. Michaek. Saldaña, Qualitative Data Analysis A Methods Sourcebook, 3rd ed. Los Angeles: Sage, 2017.

[11] N. Greene, "Inventing the French Revolution: Essays on French Political Culture in the Eighteenth Century," Hist. Rev. New Books, vol. 20, no. 3, pp. 113-113, Apr. 1992.

[12] paul edward Gottfried, "Summary for Policymakers," in Climate Change 2013 - The Physical Science Basis, Intergovernmental Panel on Climate Change, Ed. Cambridge: Cambridge University Press, 2013, pp. 1-30.

[13] D. Cunliffe, D. Morris, and C. Prys, "Young Bilinguals' Language Behaviour in Social Networking Sites: The Use of Welsh on Facebook," J. Comput. Commun., vol. 18, no. 3, pp. 339-361, Apr. 2013.

[14] O. Tsur et al., "Semi-Supervised Recognition of Sarcastic Sentences in Twitter and Amazon.," Inf. Process. Manag., 2014.

[15] T. Lickona, E. Schaps, C. Lewis, and W. Character Education Partnership DC., CEP's Eleven Principles of Effective Character Education. Washington DC: Character Education Partnership, 2007.

[16] V. A. Battistich, "Character education, prevention, and positive youth development," 2005. 